\section{Reduction in Light accompanying Exceptionally Heavy Rain}

WE are indebted to Prof. J. H. J. Poole for the suggestion that our record of illumination during very heavy rain last August might be worth studying further. We accordingly compared the data for sunshine, rainfall until 3 p.m., maximum vertical illumination in kilolux and the illumination integral in kilolux-hours for four days: August 10, clear and sunny; August 11, completely overcast sky until about 11 a.m. G.M.T.; August 14, clear and sunny; and August 15, exceptionally dark and wet until about 1 p.m. The Lynmouth flood was occasioned by the rain of August 15, falling rather later in that district.

The accompanying graph shows kilolux plotted against time, based on measurement of the charts, obtained with a Burt vacuum sodium cell and Cambridge thread recorder ${ }^{1}$; for reproduction the minute-by-minute dots were replaced by quarterhour readings, but in addition maxima and minima were included. The original chart, with current shunted to $\mathbf{0 . 2}$ for summer use, could be read to $0 \cdot 1$ scale division, corresponding to 0.35 kilolux, approximately half the vertical illumination immediately before the first appearance of the sun's disk at sunrise. One's visual impression was that at the minima, 11 a.m. and at 12.15 p.m. on August 15, the illumination was much below this; in a south window, reading was possible but not comfortable.

The high values of $V$ maximum, even on the overcast days, were due to momentary clearings in the afternoon, though the Plymouth Hoe sunshine card showed no sun on August 11 and 15.

It has been shown ${ }^{2}$ that considerable thicknesses of unbroken high cloud may still allow an apparent

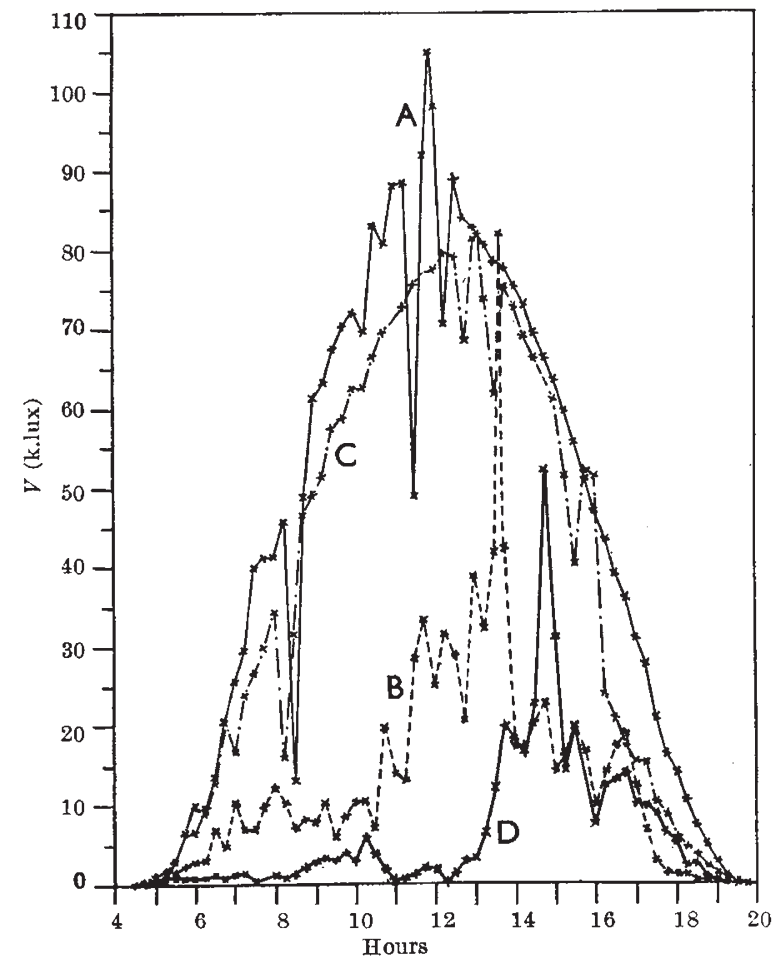

The ordinates show the vertical component of the illumination from sun and sky, in kilolux. The abscissæ show time of day.
PIYMOUTH HOF OBSERVATIONS

\begin{tabular}{|c|c|c|c|c|c|}
\hline 1952 & $\underset{(\mathrm{hr} .)}{\operatorname{Sun}}$ & $\underset{\text { (mm.) }}{\text { Rain }}$ & $\underset{(\mathrm{k} . \mathrm{lux})}{\nabla \max }$ & K.lux-hr. & $\begin{array}{l}\text { K.lux-hr. } \\
4.45 \text { until }\end{array}$ \\
\hline Aug. $\begin{array}{r}10 \\
11 \\
14 \\
15\end{array}$ & $\begin{array}{c}11 \cdot 12 \\
0 \cdot 0 \\
9 \cdot 12 \\
0 \cdot 0\end{array}$ & $\begin{array}{r}0 \\
4 \\
0 \\
82\end{array}$ & $\begin{array}{r}105 \\
82 \\
82 \\
52\end{array}$ & $\begin{array}{r}630 \\
198 \\
582 \\
96\end{array}$ & $\begin{array}{ll}39 & (10.30) \\
13 & (13.00)\end{array}$ \\
\hline
\end{tabular}

percentage transmission of $35-40$, though 1,000 $2,000 \mathrm{ft}$. of low stratus may cut the light to $20-35$ per cent around noon. But lofty cumulus or cumulonimbus cloud, with tops emergent above the total cover of the lower layers, may reduce the apparent percentage transmission to between 6 and 12 per cent if their bases are low. Unrecorded thicknesses in thunderstorms have reduced transmission to about 1 per cent. The thick cloud on August 11 reduced transmission to 8 per cent about 10.30 a.m., but on August 15 it sank at times to 0.5 per cent or less, and the integrated illumination 13 k.lux-hr. up to 1 p.m. was approximately 4.5 per cent of that for $\mathbf{a}$ clear day up to noon. The darkest day we have on record was November 29, 1934, which drizzled to about $0.7 \mathrm{k} \cdot \mathrm{lux}$ at $11 \mathrm{k} . \mathrm{m}$. and for the whole day had $14 \cdot 5 \mathrm{k} . l u x-h r$.

Since most of the water in the towering clouds indicated by the very heavy reduction in daylight must have come in from the Atlantic with relatively little smoke pollution, it is probable that reflexion from the sides and the exit from the column of scattered sunlight accounts for by far the greater part of the loss of light. Such a loss of scattered light could not occur where the sun's rays fall on a level surface of cloud.

\section{W. R. G. Atrkins \\ Pamela G. JENKINS}

Marine Biological Laboratory,

Plymouth. Jan. 21.

${ }^{1}$ Atkins, W. R. G., and Poole, H. H., Nature, 125, 305 (1030).

Atkins, W. R. G., Quart. J. Roy. Met. Soc., 7,659 (1851).

\section{Albumin: an Unsuspected Physiological Activity}

WHEN testing various fractions of human blood plasma prepared by ether precipitation in the cold ${ }^{x}$, it was found that albumin had a definite effect on the perfused rabbit's heart. In view of this, and the fact that albumin has been used for clinical transfusion for some years without any evidence of ill effect, the reaction has been studied in some detail.

Both albumin issued for clinical use (96 per cent pure) and albumin of 100 per cent purity as established by electrophoretic and ultra-centrifugal measurements have been used. If $a$ dose of $0 \cdot 3-0.5 \mathrm{ml}$. of a 3-6 per cent solution of albumin in saline $(p H \mathbf{H} \cdot 2)$ is introduced into the Ringer-Locke solution proximal to the cannula of a Langendorff rabbit-heart preparation, the following is observed. The amplitude of the ventricular beat is immediately considerably reduced; this may, or may not, be accompanied by a slowing of the heart. The coronary flow is definitely increased for a short time and is then sometimes decreased. With a dose of $0.3 \mathrm{ml}$. of 3 per cent 'pure albumin', the duration of the whole effect is about thirty seconds, after which time both the beat and the coronary flow have returned to pre-injection levels. Full atropinization does not affect the result. The change in coronary flow is not due to the alteration in heart beat, for a similar change occurs in the 